\title{
Development of Exposition Text Writing Teaching Materials With Genre Approach to Students of Grade X Vocational High School Brigjen Katamso Medan
}

\author{
Hesron Ginting ${ }^{1}$, M. Oky Gafari², Malan Lubis ${ }^{2}$ \\ ${ }^{I}$ Master Student in State University of Medan (Unimed), Medan, Indonesia \\ ${ }^{2}$ Lecturer in State University of Medan (Unimed), Medan, Indonesia \\ gintinghesron@yahoo.com
}

\begin{abstract}
The aims of this study to find the validation conducted by the material expert validator on the development of the exposition text writing module. This research used development method by using population data of all student grade X vocational high school Brigjen Katamso Medan with total 92 students. The technique of collecting data by using by simple random sampling. . The results of the validation carried out by the material expert validator on the development of the exposition text writing module with the genre approach $89.11 \%$ with the category "Very Good". The results of the validation carried out by the design expert validator on the exposition text writing module overall average value of $90.80 \%$ with the category "Very Good". The teacher's assessment of the exposition text writing module with the genre approach for grade X students obtained an average value of $80.70 \%$ in the "good" category
\end{abstract}

Keywords : development; exposition text; genre approach; vocational high school

\section{Introduction}

Education is a vehicle for developing and educating the life of the nation. A nation can develop and advance if its education functions properly. Many ways and strategies are carried out to achieve this. One of them is to replace the existing learning system. The development of the world of education in the present, requires every element of the nation to interfere in its success.

The teacher is one of the most important elements in the success of the teaching and learning process in school. Achieving quality education requires teachers as teaching staff and educators to play an active role in learning. In carrying out this, the teacher is guided by the applicable curriculum and is required to have competence in teaching. Without the teacher the teaching and learning process in the school will not run well.

Permendikbud No.20 year 2016 concerning graduate competency standards requires students to have learning competencies, namely competency, attitudes, knowledge and skills. These three competencies are the benchmark for students' graduation in learning. Based on this graduation standard, a teacher must be able to design learning in such a way. One that needs to be designed or developed is teaching material. Developing teaching materials means developing content, presentation, language, and graphics in teaching materials so that they are suitable for use by students.

Owon Research (2017) in the journal JINoP Vol. 3 No. 1 explains that teaching materials are a set of tools used by instructors in the class that contain learning material. The use of teaching materials will create a learning process that runs well. The use of teaching materials in schools must be adapted to the existing curriculum.

Indonesian Language Learning in 2013 Curriculum refers to text-based learning. In this case, students must be able to write text. One type of text that must be mastered by students of grade $\mathrm{X}$ vocational high school is exposition text. Exposition text is writing whose main purpose is clarifying, explaining, educating, or evaluating problems (Alwasilah, 2005: 111). 
Explanation or explanation is not a matter that contains opinions (arguments) but an explanation of the facts that exist.

The facts obtained in the field are not in line with expectations. Teaching materials used for grade X vocational high school Brigadier General Katamso Medan, especially the exposition text material, have deficiencies in terms of content, presentation, and evaluation used. The presentation of the material is too short, the presentation that does not attract students to learn, and the evaluation used is not appropriate. Especially for evaluations that are used should KD writing skills must be evaluated by means of writing tests (subjective tests) rather than objective tests. According to Widoyoko (2014: 125) the selection of tests must be matched with the purpose of the test, the number of test takers, the time taken, the scope of the material, and the characteristics of the subject being tested.

\section{Review of Literature}

\subsection{Teaching Materials}

Teaching materials are one of the tools to achieve competence in learning. According to Kumar (2017: 4) teaching materials as "supplementing classroom instruction to stimulate the interest of students" can be interpreted that teaching materials are materials used by teachers in learning or materials used to stimulate students' interest in learning. then according to Owon (2017) in the journal JINoP Vol. 3 No. 1 that teaching materials are a set of tools used by instructors in the class that contain learning material.

The opinion of the experts was emphasized by Prastowo (2015: 17) arguing that teaching materials are all materials (both information, tools, and texts) that are arranged systematically, which displays a complete figure of competencies that will be mastered by students and used in the learning process with the purpose of planning and reviewing the implementation of learning.

The opinions of experts above can be concluded that teaching materials are all materials that contain knowledge, skills, and attitudes that are designed systematically to be learned by students in the learning process.

\subsection{Module}

Modules are teaching materials intended for students so that they can learn independently which are arranged systematically and language adapted to their level of knowledge and age (Prastowo, 2015: 106). Furthermore, Sanjaya (2013: 331) asserts that the module is a complete stand-alone unit that is structured to help students achieve a number of learning objectives and consists of a series of learning activities.

The opinions of the experts above were confirmed by Guido (2014) in the American Journal of Educational Research, Vol. 2 No. 11 stated, "A module is defined as a self-cintained, independent unit of learning designed to help students accomplish well-defined objectives." This means that the module is defined as a separate unit and contains a series of learning activities designed to help students achieve learning goals well.

Based on the opinions of the experts above, it can be concluded, the module is a teaching material that is systematically arranged and uses language that can be understood by students to achieve learning goals.

\subsection{Writing}

To convey information to others can be done by writing. Writing is one of the language skills. According to Tarigan (2008: 3) writing is a language skill that is used to communicate 
indirectly, not face to face with other people. Furthermore, Dalman (2014: 4) added that writing is a process of conveying thoughts, delusions, feelings in the form of symbols / signs / writings that are meaningful. Both of these opinions were confirmed by Byrne (2002: 1) who said that,

"Writing involves a message of the same kind: writing, we translate our thoughts into language.... It is by the organization of our sentences into a text, into a cohenrent whole which is as explicit as possible and complete in self, that we are able to communicate successfully with our reader through the medium of writing. "

Writing is an encoding of the translation of thoughts by organizing sentences into a coherent text and explicitly has its own completeness.

\subsection{Exposition Text}

Exposition text is better known as a text that attempts to explain / explain something. According to Susanto, et al (2016) in the journal Education: Theory, Research, and Development Vol.1 No. 6 expressing exposition text is an analytic text which in the presentation of its arguments requires precision to support the writer's opinion. Furthermore, Aceng (2005: 30) explains exposition is a form of writing that is often used in conveying scientific descriptions and does not attempt to influence the opinion of readers.

The opinions of the experts above are reinforced by Dalman (2014: 120) arguing that the exposition is writing that attempts to explain or expose the opinions, ideas, beliefs of the author and requires facts that are strengthened by numbers, statistics, maps and graphics but not to influence the reader.

Based on the opinions of the hali above, it can be concluded that the exposition text is writing that aims to provide an explanation or information to the reader which is reinforced by fact data in the form of numbers, statistics, maps and graphs but not to influence the reader.

\subsection{Understanding The Genre Aproach}

Writing is basically not just writing ideas / ideas, information, or messages in a sentence that is grammatically correct. Writing must have a clear purpose. All information contained in it is packaged effectively through neatly arranged text elements in terms of rhetorical structure, and using appropriate grammar. In other words, to make effective use of language in writing must be based on genre.

Genre is interpreted as a type of text (text type) that functions as a reference pattern (frame of reference) so that the text to be made becomes effective in terms of the accuracy of objectives, word selection, text element formation, and the accuracy of grammar usage (Pardiyono, 2007: 2) . Furthermore according to Harmer (2004: 17) suggests, we refer to the specific choice of vocabulary within genres as the register that the text is written in. ... For example 'literary fiction' is a genre of English which is different from, say, 'science fiction'. ... Knowledge of genre (understanding how different purpose are commonly expressed within a discourse community) genre refers to the selection of a particular vocabulary in writing a text. For example literary fiction is a genre that is different from science fiction. Knowledge of genres (understanding how different goals in writing are expressed through genres). 


\section{Research Method}

This research is a development research which is often referred to as research and development (R \& D). According to Sujadi (2003: 164) research and development is a process or steps to develop a new product, or perfect existing products, which can be accounted for. This study develops teaching material products in the form of exposition text modules with genre approaches for grade X students of vocational hogh school Brigjen Katamso Medan.

Population is a generalization area consisting of: objects / subjects that have certain qualities and characteristics set by researchers to be studied and then conclusions drawn (Sugiyono, 2013: 80). So, the population in this study is all grade X students of vocational high school of Brigadier Katamso Medan. So, the population in this study was all grade X students of vocational high school of Brigadier Katamso Medan with a total of 92 students.

The sampling technique in this study was carried out by simple random sampling. This technique is random sampling without regard to the strata in the population. The sample in this study is grade X-2 with a total of 30 students. Population is a generalization area consisting of: objects / subjects that have certain qualities and characteristics set by researchers to be studied and then conclusions drawn (Sugiyono, 2013: 80). So, the population in this study is all grade $\mathrm{X}$ students of vocational high school of Brigadier Katamso Medan. So, the population in this study was grade X students of vocational high school of Brigadier Katamso Medan with a total of 92 students.

The sampling technique in this study was carried out by simple random sampling. This technique is random sampling without regard to the strata in the population. The sample in this study is grade X-2 with a total of 30 students.

\section{Discussion}

Research and development of teaching materials in the form of exposition text modules with a genre approach for students grade $\mathrm{X}$ vocational high school of Brigadier Katamso Medan refers to the theories of Brog and Gall which are simplified into five steps. The five steps are (1) research and information (research and information gathering); (2) develop preliminary form of product (product draft development); (3) validation test; (4) product revisions; (5) product testing. The following is an explanation of these steps.

Table.1 Results Analysis of Interview with Indonesian Language Teachers Regarding Module Needs of Exposition Texts for grade X Students at vocational high school of

Brigadier General Katamso Medan

\begin{tabular}{|l|l|l|l|l|l|}
\hline No. & Question & Answer & Teacher & Total & $\begin{array}{c}\text { \% } \\
\text { (percent) }\end{array}$ \\
\hline 1. & $\begin{array}{l}\text { Do you use models / methods / } \\
\text { strategies / approaches / } \\
\text { techniques in the learning } \\
\text { process? }\end{array}$ & No & 2 & 2 & $100 \%$ \\
\cline { 1 - 3 } 2. & $\begin{array}{l}\text { Do you use teaching materials } \\
\text { other than textbooks in carrying } \\
\text { out learning? }\end{array}$ & Yes & 2 & 2 & $100 \%$ \\
\cline { 3 - 4 } & & No & - & & \\
\hline
\end{tabular}




\begin{tabular}{|c|c|c|c|c|c|}
\hline & $\begin{array}{l}\text { Do you feel the need for } \\
\text { supporting teaching materials } \\
\text { besides the learning package } \\
\text { book? }\end{array}$ & No & - & & \\
\hline \multirow[t]{2}{*}{4.} & \multirow{2}{*}{$\begin{array}{l}\text { In your opinion, is the material of } \\
\text { exposition text writing a material } \\
\text { that is quite difficult to teach? }\end{array}$} & Yes & 2 & \multirow[t]{2}{*}{2} & $100 \%$ \\
\hline & & No & - & & \\
\hline \multirow[t]{2}{*}{5.} & \multirow{2}{*}{$\begin{array}{l}\text { Is the material in teaching } \\
\text { material that you use easy to } \\
\text { understand by students, } \\
\text { especially exposition text writing } \\
\text { material? }\end{array}$} & Yes & - & \multirow[b]{2}{*}{2} & \\
\hline & & No & 2 & & $100 \%$ \\
\hline \multirow[t]{2}{*}{6.} & \multirow{2}{*}{$\begin{array}{l}\text { Apakah anda menggunakan } \\
\text { suatu model/ metode/ strategi/ } \\
\text { teknik/pendekatan dalam } \\
\text { mengajarkan materi menulis teks } \\
\text { ekpsosisi? }\end{array}$} & Yes & 1 & \multirow{2}{*}{$\begin{array}{l}1 \\
1\end{array}$} & $50 \%$ \\
\hline & & No & 1 & & $50 \%$ \\
\hline \multirow[t]{2}{*}{7.} & \multirow{2}{*}{$\begin{array}{l}\text { Can the model / method / strategy } \\
\text { / technique / approach you use } \\
\text { improve students' exposition text } \\
\text { writing skills satisfactorily? }\end{array}$} & Yes & - & \multirow{2}{*}{-} & $50 \%$ \\
\hline & & No & 2 & & $50 \%$ \\
\hline \multirow[t]{2}{*}{8.} & \multirow{2}{*}{$\begin{array}{l}\text { Have you ever heard or found out } \\
\text { about the genre approach? }\end{array}$} & Yes & - & \multirow[b]{2}{*}{2} & \\
\hline & & No & 2 & & $100 \%$ \\
\hline \multirow[t]{2}{*}{9.} & \multirow{2}{*}{$\begin{array}{l}\text { Do you know the genre approach } \\
\text { can be used to facilitate writing } \\
\text { activities? }\end{array}$} & Yes & - & \multirow[b]{2}{*}{2} & \\
\hline & & No & 2 & & $100 \%$ \\
\hline \multirow[t]{2}{*}{10.} & \multirow{2}{*}{$\begin{array}{l}\text { What do you think if there are } \\
\text { teaching materials in the form of } \\
\text { modules developed with the } \\
\text { genre approach to writing } \\
\text { material? }\end{array}$} & $\begin{array}{l}\text { Very } \\
\text { agreeable }\end{array}$ & 2 & \multirow[t]{2}{*}{2} & $100 \%$ \\
\hline & & Disagree & - & & \\
\hline
\end{tabular}

Table.2 Questionnaire Results / Module Questionnaire Needs Writing Exposition Text For Students of Grade X Vocational High School Brigjen Katamso Medan

\begin{tabular}{|c|c|c|c|c|c|}
\hline No. & Questions & Option & Voters & $\begin{array}{c}\% \\
\text { (Percentage) }\end{array}$ & $\begin{array}{l}\text { Total } \\
\text { Students }\end{array}$ \\
\hline \multirow[t]{2}{*}{1.} & Do the Indonesian & Yes & - & - & \multirow[t]{2}{*}{92} \\
\hline & $\begin{array}{l}\text { Language study } \\
\text { modules that you } \\
\text { use contain the } \\
\text { introduction of each } \\
\text { learning activity? }\end{array}$ & No & 92 & $100 \%$ & \\
\hline \multirow[t]{2}{*}{2.} & \multirow{2}{*}{$\begin{array}{l}\text { Does the module } \\
\text { teaching material } \\
\text { that you use contain }\end{array}$} & Yes & 40 & $45,65 \%$ & \multirow[t]{2}{*}{92} \\
\hline & & No & 52 & $54,35 \%$ & \\
\hline
\end{tabular}




\begin{tabular}{|c|c|c|c|c|c|}
\hline & $\begin{array}{l}\text { detailed exposition } \\
\text { text } \quad \text { writing } \\
\text { material? }\end{array}$ & & & & \\
\hline \multirow{2}{*}{3.} & \multirow[b]{2}{*}{$\begin{array}{l}\text { Does the exposition } \\
\text { text writing } \\
\text { material in the } \\
\text { module that you use } \\
\text { use easily } \\
\text { understood } \\
\text { language? }\end{array}$} & Yes & 45 & $48,91 \%$ & \multirow[t]{2}{*}{92} \\
\hline & & No & 47 & $51,09 \%$ & \\
\hline \multirow[t]{2}{*}{4.} & \multirow[b]{2}{*}{$\begin{array}{l}\text { Does the } \\
\text { Indonesian } \\
\text { Language study } \\
\text { module that you use } \\
\text { have an attractive } \\
\text { design? }\end{array}$} & Yes & 20 & $21,74 \%$ & \multirow[t]{2}{*}{92} \\
\hline & & No & 72 & $78,26 \%$ & \\
\hline \multirow[t]{2}{*}{5.} & \multirow[b]{2}{*}{$\begin{array}{l}\text { Does the } \\
\text { Indonesian } \\
\text { language study } \\
\text { module that uses } \\
\text { the combination of } \\
\text { writing, drawing } \\
\text { and decoration } \\
\text { types add to the } \\
\text { attractiveness of the } \\
\text { module? }\end{array}$} & Yes & 9 & $9,78 \%$ & \multirow[t]{2}{*}{92} \\
\hline & & No & 83 & $90,22 \%$ & \\
\hline \multirow[t]{2}{*}{6.} & \multirow[b]{2}{*}{$\begin{array}{l}\text { Can the Indonesian } \\
\text { Language study } \\
\text { module you use } \\
\text { contain steps for } \\
\text { writing exposition } \\
\text { text in detail? }\end{array}$} & Yes & - & - & \multirow[t]{2}{*}{92} \\
\hline & & No & 92 & $100 \%$ & \\
\hline \multirow[t]{2}{*}{7.} & \multirow[b]{2}{*}{$\begin{array}{l}\text { If there are steps to } \\
\text { write exposition } \\
\text { text loaded in the } \\
\text { module that you are } \\
\text { using, do you think } \\
\text { these steps are easy } \\
\text { to do in writing } \\
\text { exposition text? }\end{array}$} & Yes & - & - & \multirow[t]{2}{*}{92} \\
\hline & & No & 92 & $100 \%$ & \\
\hline \multirow[t]{2}{*}{8.} & \multirow{2}{*}{$\begin{array}{l}\text { Apakah modul yang } \\
\text { kamu gunakan } \\
\text { dapat } \\
\text { meningkatkan } \\
\text { keterampilan kamu }\end{array}$} & Yes & 10 & $10,87 \%$ & \multirow[t]{2}{*}{92} \\
\hline & & No & 82 & $89,13 \%$ & \\
\hline
\end{tabular}




\begin{tabular}{|l|l|l|l|l|l|}
\hline & $\begin{array}{l}\text { dalam menulis teks } \\
\text { eksposisi? }\end{array}$ & & & \\
\hline 9. & $\begin{array}{l}\text { Do you think that } \\
\text { the Indonesian } \\
\text { Language Study } \\
\text { module that you are } \\
\text { studying still needs } \\
\text { to be developed? }\end{array}$ & No & - & 92 & $100 \%$ \\
\hline 10. & $\begin{array}{l}\text { Have you ever } \\
\text { heard or found out } \\
\text { about the genre } \\
\text { approach so useful } \\
\text { for } \\
\text { activities? writing }\end{array}$ & No & - & - & 92 \\
\hline 11. & $\begin{array}{l}\text { What do you think } \\
\text { if there are teaching } \\
\text { materials for for } \\
\text { exposition text } \\
\text { writing developed } \\
\text { with the genre } \\
\text { approach? }\end{array}$ & Disagree & - & $-100 \%$ & 92 \\
\hline
\end{tabular}

After the information collection phase is carried out, the next step is to develop module teaching materials. The first step is to determine the module title, namely "Module Writing Exposition Text for Grade X Students of Vocational School; Development of Teaching Materials with Genre Approach ". After the title is set, the next step is the determination of learning objectives, the learning material selector, the framework of the exposition text module, and collecting learning materials. The following is an explanation of the stages after determining the title of the module.

The objectives of learning in this module are two general and specific objectives. The general objective is that students are expected to be able to write exposition texts based on the genre approach. While the specific objectives are 1) Students are able to understand the meaning along with exposition text structure. 2) Students are able to write ekpsosisi text according to the structure and spelling of Indonesian language that is good and correct.

The selection of learning materials in this case is the selection of learning resources which will later be used as references in the module. This selection is done to adjust the theory, concepts, images, and texts on basic competencies. Apart from that, this selection is also done to suit the characteristics of the students both from the material and the language used.

The preparation of this module framework is done to facilitate later in making the module. Apart from that, the preparation of this module also helps the author to see parts of the module that are incomplete or excessive. The preparation of the module framework starts with the introduction of the module (introduction, table of contents, background, brief description, basic competencies, concept maps, benefits, learning objectives, and module usage instructions), module contents (introduction, keywords, achievement indicators, titles, subtitles, exercises, and answer keys), and closing modules (summary, glossary, and bibliography). 
The next step taken after the module framework is created is to collect materials. This activity is carried out to find all information about material, theory, or even concepts. The source is obtained from various book, module, and internet (online) references. The purpose of these various sources is obtained from many references so that the contents of the module which will be made to have material that is complete and can be used by students easily.

After the four activities above are carried out, the next step is making modules. The making of this module uses A4 paper $(21 \mathrm{~cm} \times 29.7 \mathrm{~cm})$ and has three parts, namely 1) the cover and the introduction to the module; 2) content section; and 3) the closing part of the module. The following is an explanation of each of the three parts of the module.

First, the cover and introduction of the module. On the cover there is the title "Text Module Writing Exposition for Grade X Students of Vocational School; Development of Teaching Materials with Genre Approach ". Apart from that there are also Unimed and 2013 Curriculum logos, author names and illustrated images of writing activities. Following is the exposition text module cover image.

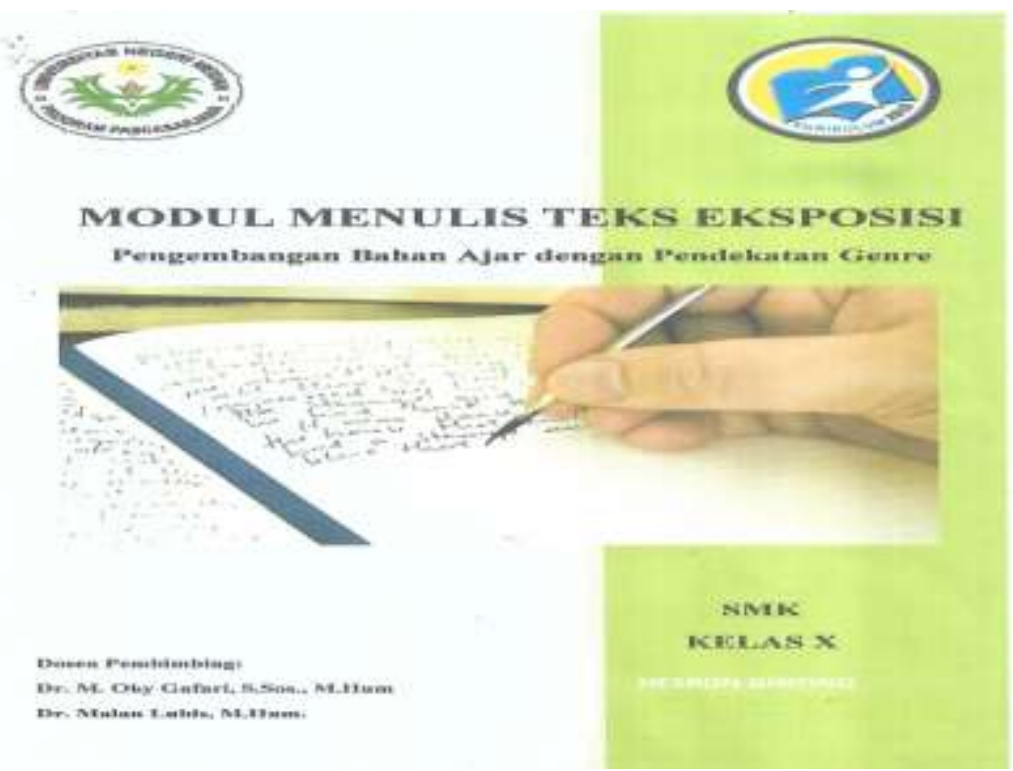

Figure 1.Module Cover Writing Exposition Text for Grade X Vocational Students

Furthermore, in the introduction section the module contains preface, table of contents, description of the module, and module introduction (background, brief description, basic competencies, concept maps, benefits, learning objectives, and module usage instructions). In the foreword section, it contains an introductory word from the author regarding thanks to God, lecturer validation (material and design expert) and the overall contents of the module. The table of contents contains pages of discussion topics in the module.

Furthermore, in the introductory section of the module, namely (1) Background, contains the background for making modules that are adapted to the 2013 curriculum and developed with the genre approach. (2) A brief description, containing about the topics that will be discussed in the module. (3) Basic competition, containing 4 (four) KD exposition texts that will be achieved later. (4) Concept map, containing the elaboration of the four KDs that are contained in the form of a diagram. (5) Learning benefits and objectives, containing benefits and objectives after studying the module. (6) Instructions for using the module, containing a description of the procedure for using the module. 
Second, the module contents section. This section contains learning material that is equipped with exercises, key answers, and how to evaluate them. Especially in exposition text writing subject matter developed with the genre approach. The following is a glimpse of the contents of the module which is equipped with exercises, keys, answers, and methods of assessment.
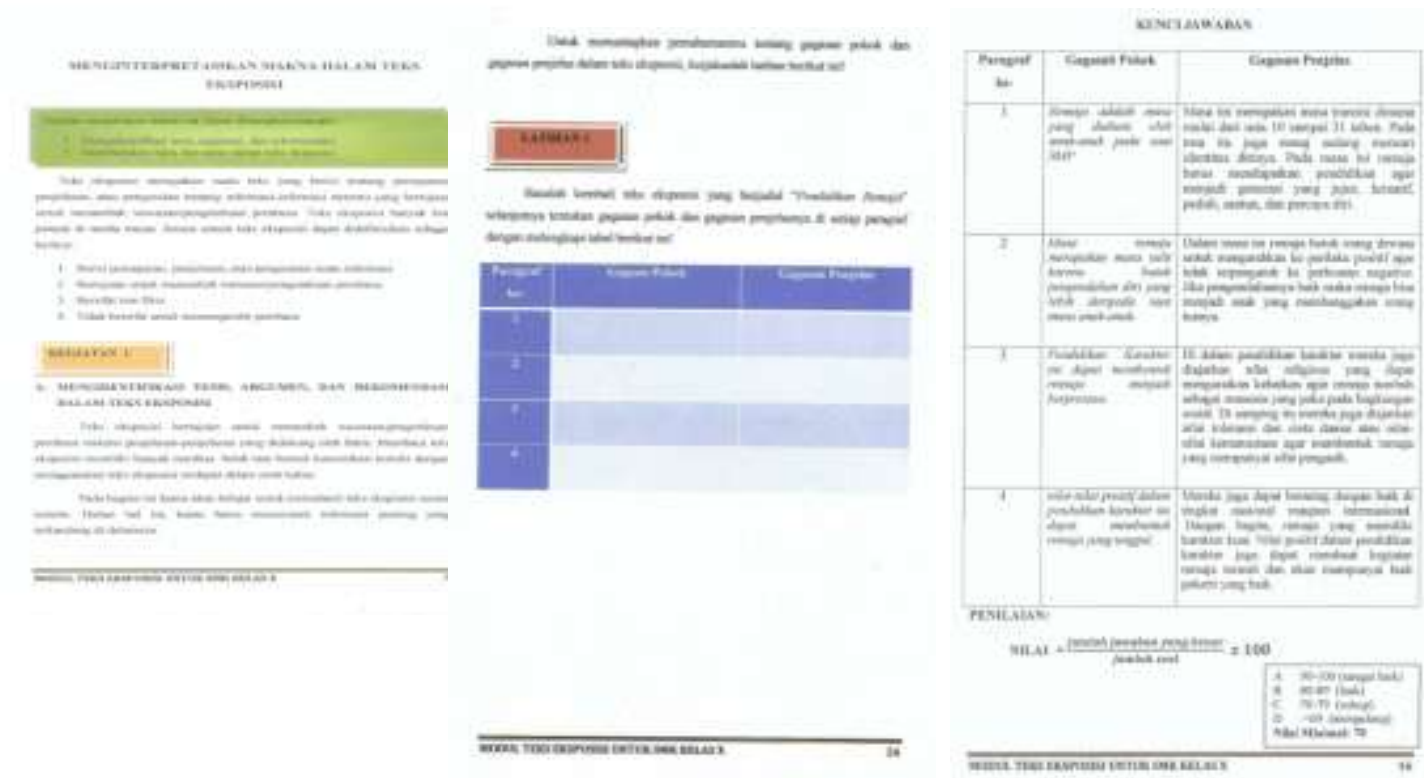

Figure 2 The Contents of Module

Third, the closing part of the module. The concluding section of this module contains a summary of the material, glossary, and bibliography. The material summary contains the essence of the entire material in the module. glossary contains the meaning of words that are considered difficult in the module. Furthermore, the bibliography contains reading references used by the author in compiling the module.

Table 3. Table Results of the Expert Material Validation of the Module for Writing Exposition Texts for Grade X Students of Vocational School

\begin{tabular}{|c|c|c|c|c|c|c|}
\hline \multicolumn{7}{|c|}{ I. Feasibility Aspects of Materials } \\
\hline No. & Indicator & $\mathrm{X}_{1}$ & $\mathbf{X}_{\mathbf{2}}$ & Total & Percentage & Category \\
\hline 1. & $\begin{array}{l}\text { Conformity of the material with } \\
\text { the KD and learning objectives }\end{array}$ & 4 & 4 & 8 & $80 \%$ & Good \\
\hline 2. & $\begin{array}{l}\text { The concept of material is } \\
\text { reviewed in terms of science }\end{array}$ & 4 & 4 & 8 & $80 \%$ & Good \\
\hline 3. & Clarity of learning topics & 5 & 4 & 9 & $90 \%$ & Very good \\
\hline 4. & Collapse Of Learning Material & 4 & 5 & 9 & $90 \%$ & Very good \\
\hline 5. & scope of learning materials & 5 & 5 & 10 & $100 \%$ & Very good \\
\hline 6. & learning material proximity & 4 & 4 & 8 & $80 \%$ & Good \\
\hline
\end{tabular}




\begin{tabular}{|c|c|c|c|c|c|c|}
\hline 7. & $\begin{array}{l}\text { Conformity of difficulty level } \\
\text { with cognitive of grade } X \text { of } \\
\text { vocational high school }\end{array}$ & 4 & 4 & 8 & $80 \%$ & Good \\
\hline 8. & $\begin{array}{l}\text { The interrelationship of } \\
\text { learning materials with students' } \\
\text { daily lives }\end{array}$ & 4 & 3 & 7 & $70 \%$ & good \\
\hline 9. & Clarity of given example & 4 & 4 & 8 & $80 \%$ & Good \\
\hline 10. & $\begin{array}{l}\text { Material suitability with self- } \\
\text { study concept }\end{array}$ & 4 & 5 & 9 & $90 \%$ & Very good \\
\hline 11. & $\begin{array}{lcr}\begin{array}{l}\text { Compatibility } \\
\text { evaluation } \\
\text { competence }\end{array} & \begin{array}{c}\text { of } \\
\text { with }\end{array} & \begin{array}{r}\text { learning } \\
\text { basic }\end{array} \\
& & \\
\end{array}$ & 4 & 4 & 8 & $80 \%$ & Good \\
\hline 12. & $\begin{array}{l}\text { The key truth answers the } \\
\text { matter correctly }\end{array}$ & 4 & 4 & 8 & $80 \%$ & Good \\
\hline 13. & $\begin{array}{l}\text { Material precision with } \\
\text { exposition text theory }\end{array}$ & 4 & 5 & 9 & $90 \%$ & Very good \\
\hline 14. & $\begin{array}{l}\text { The charge of cognitive, } \\
\text { psychomotor, and affective } \\
\text { aspects on the material } \\
\text { presented on the module }\end{array}$ & 5 & 4 & 9 & $90 \%$ & Very good \\
\hline \multicolumn{4}{|c|}{ Average } & 8,42 & $84,28 \%$ & Very good \\
\hline \multicolumn{7}{|c|}{ II. Feasibility Aspects of Language } \\
\hline 1. & $\begin{array}{l}\text { Clarity of instructions for the } \\
\text { use of learning materials }\end{array}$ & 5 & 5 & 10 & $100 \%$ & Very good \\
\hline 2. & $\begin{array}{l}\text { The accuracy of the use of the } \\
\text { term }\end{array}$ & 4 & 4 & 8 & $80 \%$ & Good \\
\hline 3. & $\begin{array}{l}\text { The use of language that is } \\
\text { easily understood by students }\end{array}$ & 5 & 5 & 10 & $100 \%$ & Very good \\
\hline 4. & Use of polite language & 5 & 5 & 10 & $100 \%$ & Very good \\
\hline \multicolumn{4}{|c|}{ Average } & $\mathbf{9 , 5}$ & $95 \%$ & Very good \\
\hline \multicolumn{7}{|c|}{ III. Aspects of Feasibility of Presentation } \\
\hline 1. & $\begin{array}{l}\text { Learning material modules that } \\
\text { support student involvement in } \\
\text { the learning process }\end{array}$ & 5 & 5 & 10 & $100 \%$ & Very good \\
\hline 2. & $\begin{array}{l}\text { Presentation of images in } \\
\text { modules }\end{array}$ & 5 & 4 & 9 & $90 \%$ & Very good \\
\hline 3. & $\begin{array}{l}\text { Complete presentation in the } \\
\text { module }\end{array}$ & 5 & 4 & 9 & $90 \%$ & Very good \\
\hline \multicolumn{4}{|c|}{ Average } & 9,33 & $93,33 \%$ & Very good \\
\hline \multicolumn{7}{|c|}{ IV. Material Effect Aspects of Learning } \\
\hline 1. & Easyness in its use & 5 & 4 & 9 & $90 \%$ & Very good \\
\hline 2. & $\begin{array}{l}\text { Support of learning materials } \\
\text { that make it easier for students } \\
\text { to learn independently }\end{array}$ & 5 & 5 & 10 & $100 \%$ & Very good \\
\hline
\end{tabular}




\begin{tabular}{|c|c|c|c|c|c|c|}
\hline 3. & $\begin{array}{l}\text { The ability of learning materials } \\
\text { that can increase student } \\
\text { motivation in learning }\end{array}$ & 4 & 4 & 8 & $80 \%$ & Good \\
\hline 4. & $\begin{array}{l}\text { The ability of learning material } \\
\text { to increase students' (cognitive) } \\
\text { knowledge }\end{array}$ & 4 & 5 & 9 & $90 \%$ & Very good \\
\hline 5. & $\begin{array}{l}\text { The ability of learning materials } \\
\text { to add insight to students }\end{array}$ & 4 & 4 & 8 & $80 \%$ & Good \\
\hline \multicolumn{4}{|c|}{ Average } & $\mathbf{8 , 8}$ & $\mathbf{8 8 \%}$ & Very good \\
\hline \multicolumn{7}{|c|}{ V. Comprehensive Display Aspects } \\
\hline 1. & Module cover exploration & 4 & 4 & 8 & $80 \%$ & Good \\
\hline 2. & $\begin{array}{l}\text { Ease of reading module } \\
\text { contents (text / writing) }\end{array}$ & 4 & 5 & 9 & $90 \%$ & Very good \\
\hline \multicolumn{4}{|c|}{ Average } & 8,5 & $85 \%$ & Very good \\
\hline \multicolumn{4}{|c|}{ Total overall average } & 8,9 & $89,11 \%$ & Very good \\
\hline
\end{tabular}

The results of validation analition by both the above material expert validators obtained the total overall average validation module writing exposition text for the grade $\mathrm{X}$ Vocational high school of $89.11 \%$ with excellent category. Here are details of the acquisition of the average value of each indicator based on the validation of the material expert. First, the material feasibility aspect obtained an average value of eligibility of $84.28 \%$ with excellent categories. Second, the feasibility aspect of language is obtained an average value of $95 \%$ with excellent categories. Third, the feasibility aspect of presentation is obtained an average value of $93.33 \%$ with excellent categories. Fourth, the aspect of the effect of matter on learning is obtained an average value of $88 \%$ with excellent categories. Fifth, the aspect of thorough display is obtained an average value of $89.11 \%$ with excellent categories. Based on the acquisition of that average value the data is concluded that the exposition text module for the grade $\mathrm{X}$ Vocational high school is worth testing into the field.

Table 4. Validation Results of Design Experts on Exposition Text Writing Module for vocational High School grade X Student

\begin{tabular}{|c|c|c|c|c|c|c|}
\hline No. & Indicator & $\mathbf{X}_{1}$ & $\mathbf{X}_{2}$ & Total & Percentage & Category \\
\hline \multicolumn{7}{|c|}{ I. $\quad$ Module Size } \\
\hline 1. & $\begin{array}{l}\text { Kesesuaian ukuran modul } \\
\text { dengan standar ISO: A4 }(210 \mathrm{~mm} \\
\text { x } 297 \mathrm{~mm})\end{array}$ & 5 & 5 & 10 & $100 \%$ & Very goo \\
\hline \multicolumn{2}{|c|}{ Average } & \multicolumn{2}{|l|}{5} & \multicolumn{2}{|l|}{$100 \%$} & Very good \\
\hline \multicolumn{7}{|c|}{ II. $\quad$ Module Cover Design } \\
\hline 1. & $\begin{array}{l}\text { The images and letters used in the } \\
\text { module cover are interesting and } \\
\text { easy to read }\end{array}$ & 4 & 5 & 9 & $90 \%$ & Very good \\
\hline \multicolumn{2}{|c|}{ Average } & \multicolumn{2}{|c|}{4,5} & \multicolumn{2}{|l|}{$90 \%$} & Very good \\
\hline \multicolumn{7}{|c|}{ III. Design of Module Contents Layout } \\
\hline 1. & $\begin{array}{l}\text { The module contents layout is } \\
\text { consistent }\end{array}$ & 4 & 5 & 9 & $90 \%$ & Very good \\
\hline
\end{tabular}




\begin{tabular}{|c|c|c|c|c|c|c|}
\hline 2. & $\begin{array}{l}\text { The layout of harmonic module } \\
\text { content elements }\end{array}$ & 4 & 4 & 8 & $80 \%$ & Good \\
\hline 3. & $\begin{array}{l}\text { Placement and appearance of } \\
\text { module element layouts (chapter } \\
\text { title, chapter sub, illustration, } \\
\text { empty space }\end{array}$ & 4 & 5 & 9 & $90 \%$ & Very good \\
\hline 4. & $\begin{array}{l}\text { The layout of the illustration / } \\
\text { decoration placement does not } \\
\text { interfere with the title, text, and } \\
\text { module pages }\end{array}$ & 4 & 5 & 9 & $90 \%$ & Very good \\
\hline 5. & $\begin{array}{l}\text { The layout of the placement of } \\
\text { titles, subtitles, illustrations / } \\
\text { decorations does not interfere } \\
\text { with understanding }\end{array}$ & 4 & 4 & 8 & $80 \%$ & Good \\
\hline \multicolumn{2}{|c|}{ Average } & \multicolumn{2}{|l|}{4,3} & \multicolumn{2}{|c|}{$86 \%$} & Very good \\
\hline \multicolumn{7}{|c|}{ of Module Content } \\
\hline 1. & Tifografi sederhana & 4 & 4 & 8 & $80 \%$ & Good \\
\hline 2. & Typography is easy to read & 4 & 5 & 9 & $90 \%$ & Very good \\
\hline 3. & $\begin{array}{l}\text { Tipografi dapat menambah } \\
\text { pemahaman }\end{array}$ & 4 & 4 & 8 & $80 \%$ & Good \\
\hline \multicolumn{2}{|c|}{ Average } & \multicolumn{2}{|c|}{4,16} & \multicolumn{2}{|c|}{$83 \%$} & Good \\
\hline \multicolumn{7}{|c|}{ V. Illustration Aspects of Module Content } \\
\hline 1. & $\begin{array}{l}\text { Illustrations clarify and add to } \\
\text { understanding }\end{array}$ & 5 & 5 & 10 & $100 \%$ & Very good \\
\hline 2. & Illustration has an attraction & 4 & 5 & 9 & $90 \%$ & Very good \\
\hline \multicolumn{2}{|c|}{ Average } & \multicolumn{2}{|c|}{4,75} & \multicolumn{2}{|c|}{$95 \%$} & Very good \\
\hline \multicolumn{2}{|c|}{ Overall total } & \multicolumn{2}{|c|}{$\mathbf{4 , 5 4}$} & \multicolumn{2}{|c|}{$90,80 \%$} & Very good \\
\hline
\end{tabular}

Grouping validation results from material experts and design experts against exposition text modules for high school X class students can be seen in the following table.

Table 5. Grouping of Validation Results By Material and Design Experts

\begin{tabular}{|l|l|l|l|l|}
\hline No. & Validator & Percentage & $\begin{array}{l}\text { Validator } \\
\text { average }\end{array}$ & Categoty \\
\hline 1. & Material Expert & $89,11 \%$ & $89,95 \%$ & Very good \\
\hline 2. & Design expert & $90,80 \%$ & 8 & \\
\hline
\end{tabular}

Grouping of percentation results from validation performed by material experts and design experts in the table above can be concluded that the development of exposition text modules with genre approaches for high school X graders is earned a grade of $89.95 \%$ with excellent categories. The acquisition of average values based on the results of the validation of material experts and design experts can be concluded that the exposition text module can be declared feasible to be tested into the field. Comparison of such validation results in detail can be seen in the following diagram. 


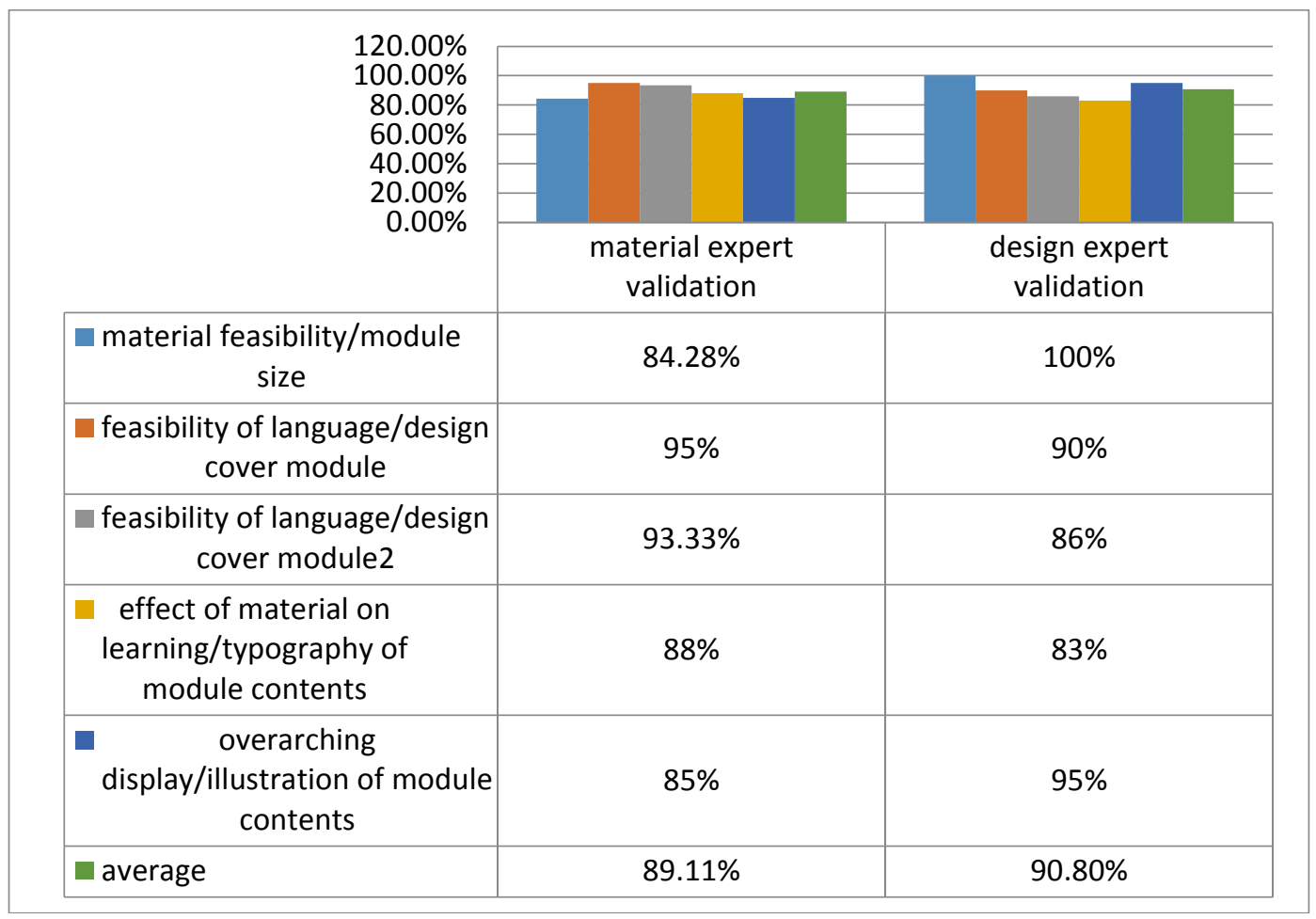

Diagram 4.1 Details of Results of Material Expert Validation and Design Expert
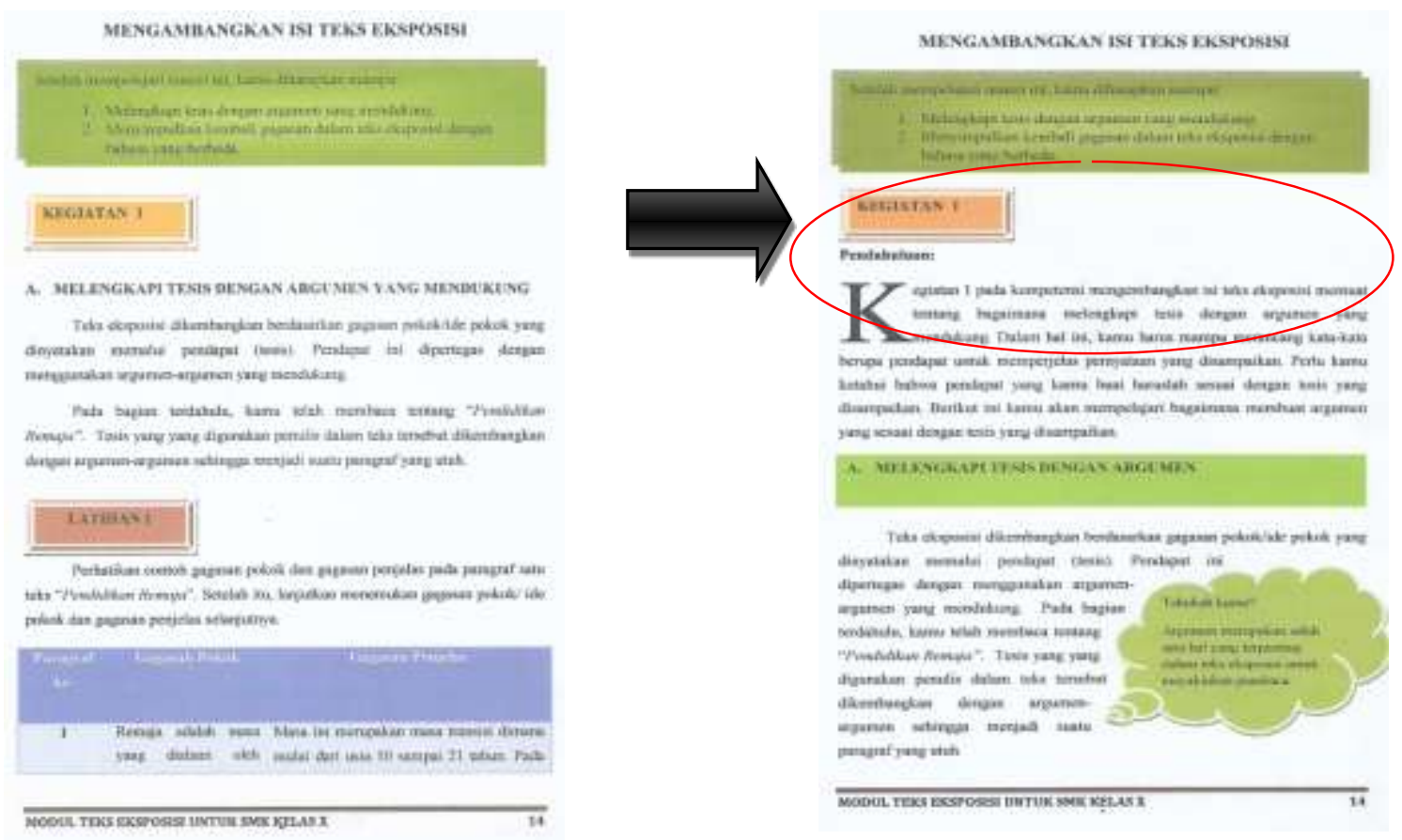

Figure 3. Revised Results from Validator Material Expert

The second revision was made by the design expert validator. The revision made by the associated design expert validators on the exposition text module for the X-grade students of SMK. As for the revision made by the design expert validator that is the feasibility of grafficing the module. The feasibility of such graffiti is 1) Addition of decoration on modules to attract 
students' attention in learning. 2) Addition of the word wise to fill empty space and as a student's motivation for learning. 3) Usage drop cap to make letter variations to be interesting. The following will display the revision already done.
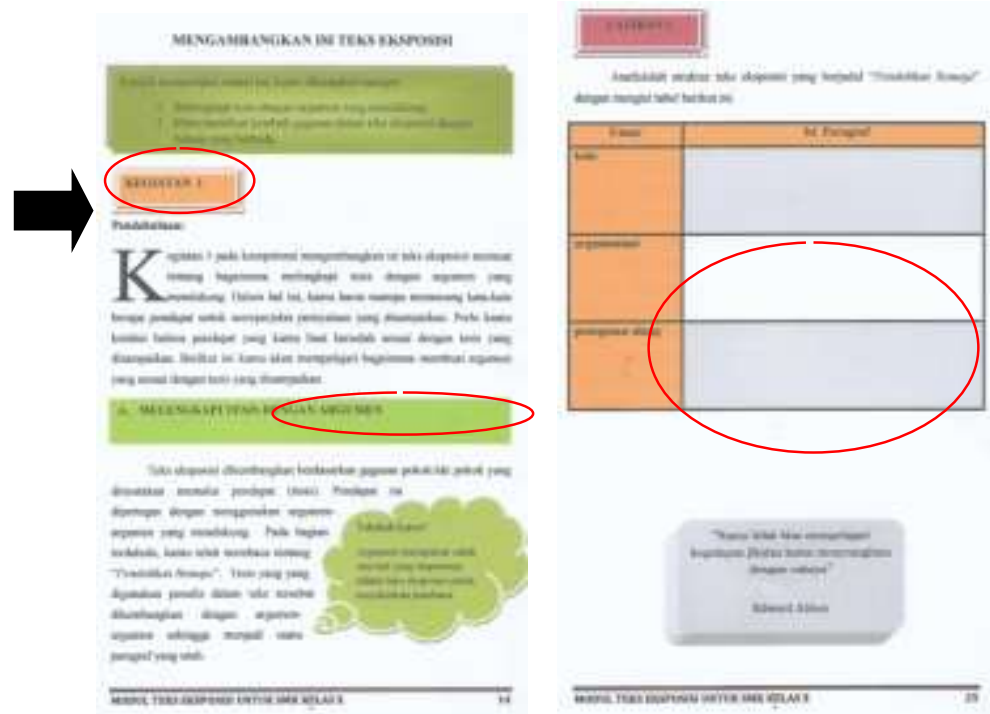

Figure 4. Revised Results of the Validator of Design Experts

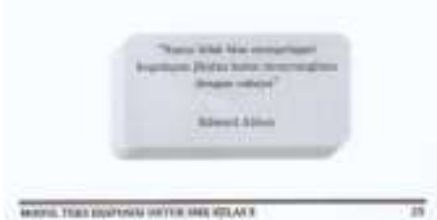

The exposition text writing module for X-grade SMK students is assessed by the teacher of the field of Indonesian Language studies at Brigjen Katamso Medan High School. This assessment involved two teachers namely Herman, S.Pd. and Yusniar, S.Pd. Here are the results of the assessments conducted by the two teachers.

Table 6. The Outcomes of Teachers`Assessment of Indonesian Language Studies Against Exposition Text Writing Module for Grade X Student vocational High School Brigjen Katamso Medan

\begin{tabular}{|l|l|l|l|l|l|}
\hline Aspect & No. & Assessment Indicator & Total. & Average & Category \\
\hline $\begin{array}{l}\text { contents/learning } \\
\text { materials }\end{array}$ & 1. & $\begin{array}{l}\text { Suitability of learning } \\
\text { materials with basic } \\
\text { competence }\end{array}$ & 9 & $90 \%$ & Very good \\
\cline { 2 - 6 } & 2. & $\begin{array}{l}\text { clarity of learning } \\
\text { material }\end{array}$ & 9 & $90 \%$ & Very good \\
\cline { 2 - 6 } & 3. & $\begin{array}{l}\text { Accuracy and } \\
\text { correctness of learning } \\
\text { material }\end{array}$ & 8 & $80 \%$ & Good \\
\cline { 2 - 6 } & 4. & $\begin{array}{l}\text { Completeness of } \\
\text { exposition text writing } \\
\text { material }\end{array}$ & 8 & $80 \%$ & Good \\
\cline { 2 - 6 } & 5. & $\begin{array}{l}\text { There are steps in } \\
\text { writing } \\
\text { exposition text }\end{array}$ & 9 & $90 \%$ & Very good \\
\cline { 2 - 6 } & 6. & $\begin{array}{l}\text { Kesesuaian instrumen } \\
\text { soal dengan kompetensi } \\
\text { yang dicapai }\end{array}$ & 9 & $90 \%$ & Very good \\
\hline
\end{tabular}




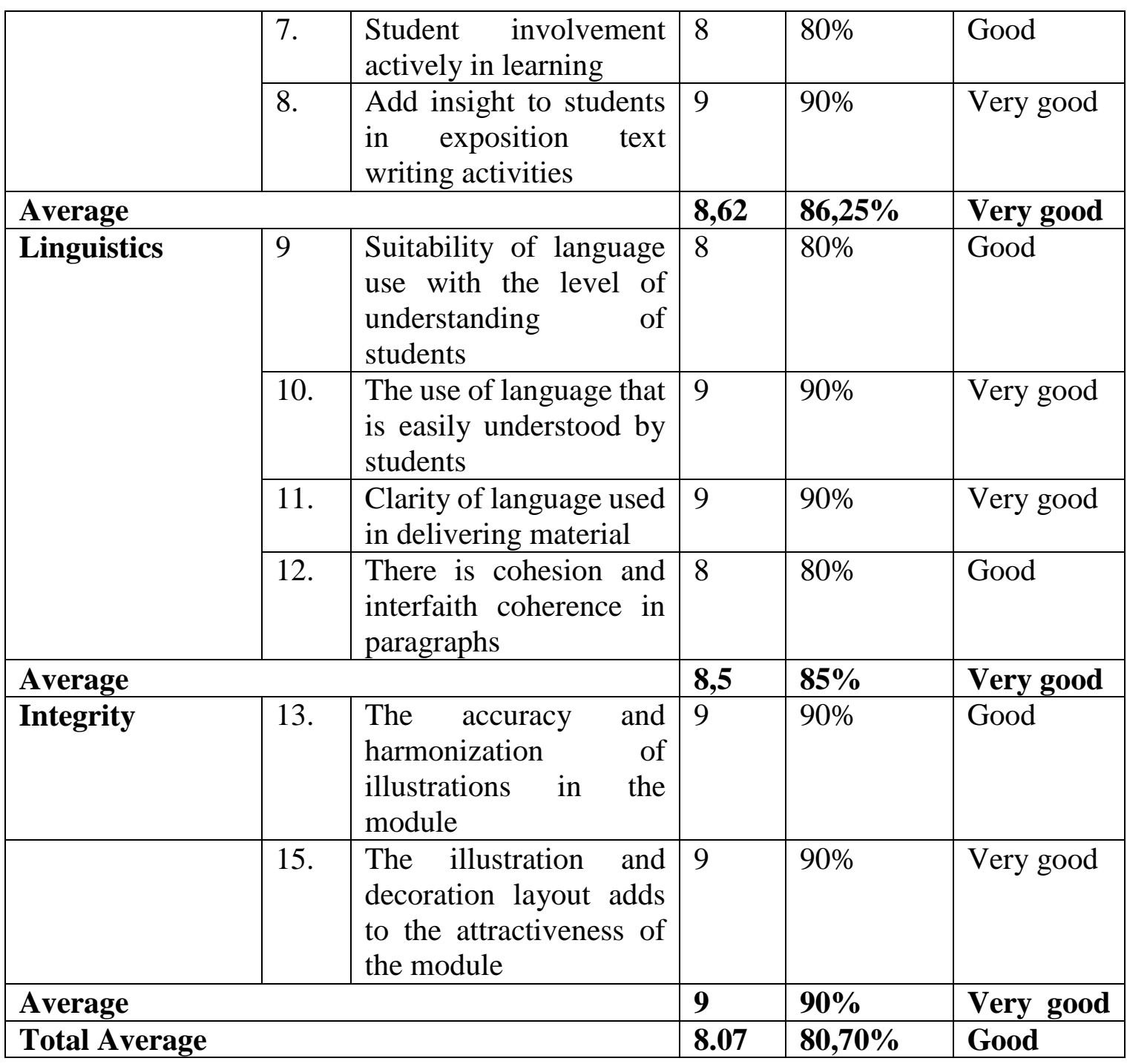

Table 7. Individual Test Results Against the Module Writing Exposition Text

\begin{tabular}{|l|l|l|l|l|l|l|l|l|}
\hline \multirow{2}{*}{ No. } & \multirow{2}{*}{ Indikator penilaian } & \multicolumn{2}{|l|}{ Respondents } & \multirow{2}{*}{ Total } & Percentage & Category \\
\cline { 2 - 8 } & $\mathbf{1}$ & $\mathbf{2}$ & $\mathbf{3}$ & & & \\
\hline Quality of learning material & $\begin{array}{l}\text { Is the learning material of } \\
\text { exposition text writing } \\
\text { easy for you to } \\
\text { understand }\end{array}$ & 4 & 4 & 5 & 13 & $86,66 \%$ & Very good \\
\hline 2. & $\begin{array}{l}\text { Do you understand the } \\
\text { language used in the } \\
\text { module }\end{array}$ & 4 & 4 & 4 & 12 & $80 \%$ & Good \\
\hline 3. & $\begin{array}{l}\text { Is there a part of learning } \\
\text { material in writing } \\
\text { exposition text that is } \\
\text { difficult for you to } \\
\text { understand }\end{array}$ & 4 & 4 & 14 & $93,33 \%$ & Very good \\
\hline
\end{tabular}




\begin{tabular}{|c|c|c|c|c|c|c|c|}
\hline 4. & $\begin{array}{l}\text { Can you understand the } \\
\text { usefulness of the genre } \\
\text { approach in writing }\end{array}$ & 5 & 4 & 4 & 13 & $86,66 \%$ & Very good \\
\hline 5 . & $\begin{array}{l}\text { Can you do the steps to } \\
\text { write exposition text with } \\
\text { the genre approach }\end{array}$ & 4 & 4 & 4 & 12 & $80 \%$ & Good \\
\hline 6. & $\begin{array}{l}\text { Does your skill in writing } \\
\text { exposition text after } \\
\text { learning the module } \\
\text { increase }\end{array}$ & 5 & 4 & 4 & 13 & $86,66 \%$ & Very good \\
\hline 7. & $\begin{array}{l}\text { Is the exposition text } \\
\text { module able to lead you } \\
\text { to self-study }\end{array}$ & 4 & 4 & 4 & 12 & $80 \%$ & Good \\
\hline 8. & $\begin{array}{l}\text { What do you think the } \\
\text { material's slick in the } \\
\text { module }\end{array}$ & 5 & 5 & 4 & 14 & $93,33 \%$ & Very good \\
\hline \multicolumn{5}{|c|}{ Average } & 12,87 & $85,83 \%$ & Very good \\
\hline \multicolumn{8}{|c|}{ Graphical quality (display) } \\
\hline 1. & $\begin{array}{l}\text { Can the illustrations used } \\
\text { in the module add to your } \\
\text { profile }\end{array}$ & 4 & 5 & 5 & 14 & $93,33 \%$ & Very good \\
\hline 2. & $\begin{array}{l}\text { Whether the decorations } \\
\text { used in the module can } \\
\text { add to your attractiveness } \\
\text { in learning modules }\end{array}$ & 5 & 5 & 5 & 15 & $100 \%$ & Very good \\
\hline 3. & $\begin{array}{l}\text { Whether the motivational } \\
\text { words contained in the } \\
\text { module can guide you in } \\
\text { learning }\end{array}$ & 5 & 5 & 5 & 15 & $100 \%$ & Very good \\
\hline 4. & $\begin{array}{l}\text { What is the readability of } \\
\text { the text contained in the } \\
\text { module }\end{array}$ & 4 & 4 & 4 & 12 & $80 \%$ & Good \\
\hline 5. & $\begin{array}{l}\text { What is the arrangement } \\
\text { or form of words / } \\
\text { sentences in the module }\end{array}$ & 4 & 4 & 4 & 12 & $80 \%$ & Good \\
\hline \multicolumn{5}{|c|}{ Average } & 13,60 & $90,66 \%$ & Very good \\
\hline \multicolumn{5}{|c|}{ Total All Average } & 13,23 & $88,23 \%$ & Very good \\
\hline
\end{tabular}




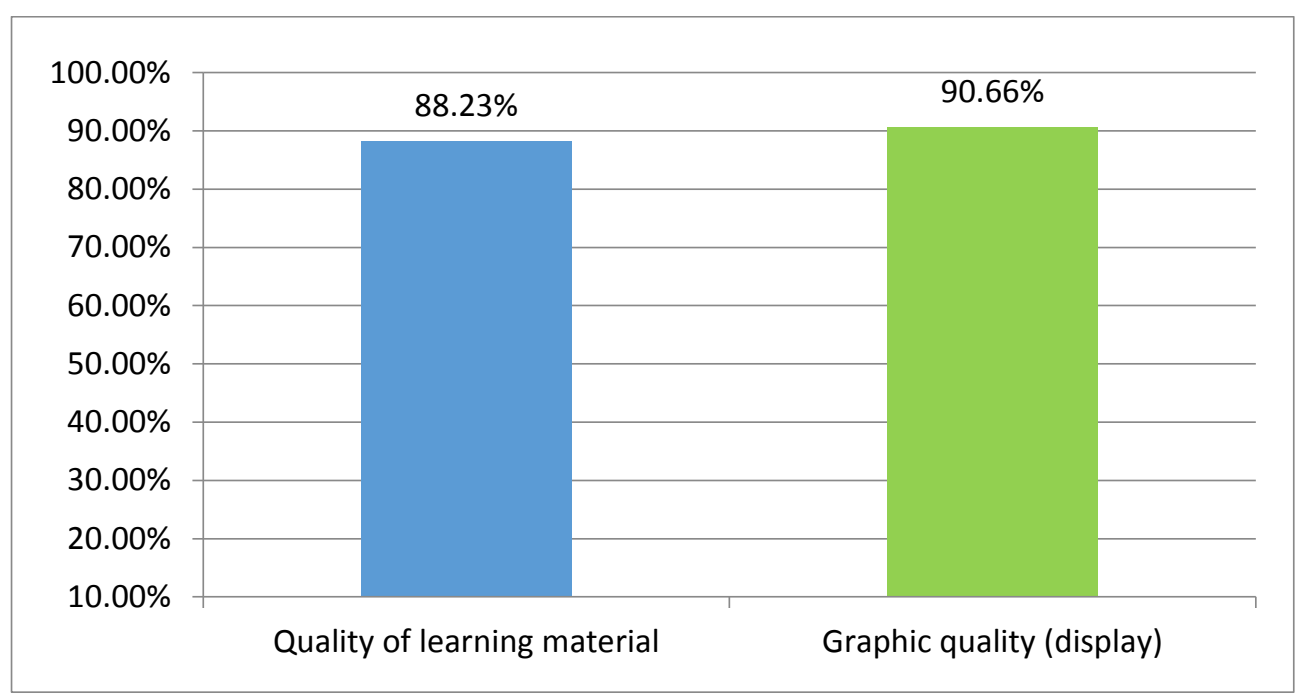

Diagram 2. Percentage of Individual Trial Acquisition

Table 8 . Small Group Test Results on Exposition Text Writing Module

\begin{tabular}{|c|c|c|c|c|c|c|c|c|c|c|c|c|}
\hline \multirow[t]{2}{*}{ No } & \multirow{2}{*}{$\begin{array}{l}\text { Assessment } \\
\text { indicators }\end{array}$} & \multicolumn{9}{|c|}{ Respondents } & \multirow[t]{2}{*}{ Percentage } & \multirow[t]{2}{*}{ Category } \\
\hline & & 1 & 2 & 3 & 4 & 5 & 6 & 7 & 8 & 9 & & \\
\hline \multicolumn{13}{|c|}{ Quality of Learning Materials } \\
\hline 1. & $\begin{array}{l}\text { Is the learning } \\
\text { material of } \\
\text { exposition text } \\
\text { writing easy } \\
\text { for you to } \\
\text { understand }\end{array}$ & 5 & 4 & 5 & 4 & 5 & 4 & 4 & 5 & 4 & $88,88 \%$ & Very good \\
\hline 2. & $\begin{array}{l}\text { Do you } \\
\text { understand the } \\
\text { language used } \\
\text { in the module }\end{array}$ & 4 & 4 & 4 & 4 & 4 & 5 & 4 & 4 & 4 & $82,22 \%$ & Good \\
\hline 3. & $\begin{array}{l}\text { Is there a part } \\
\text { of learning } \\
\text { material in } \\
\text { writing } \\
\text { exposition text } \\
\text { that is difficult } \\
\text { for you to } \\
\text { understand }\end{array}$ & 4 & 5 & 4 & 4 & 5 & 4 & 4 & 5 & 4 & $86,66 \%$ & Very good \\
\hline 4. & $\begin{array}{l}\text { Can you } \\
\text { understand the } \\
\text { usefulness of } \\
\text { the genre } \\
\text { approach in } \\
\text { writing }\end{array}$ & 4 & 4 & 5 & 4 & 4 & 4 & 4 & 4 & 4 & $82,22 \%$ & Good \\
\hline 5. & $\begin{array}{l}\text { Can you do the } \\
\text { steps to write }\end{array}$ & 4 & 4 & 5 & 4 & 4 & 5 & 4 & 5 & 4 & $86,66 \%$ & Very good \\
\hline
\end{tabular}




\begin{tabular}{|c|c|c|c|c|c|c|c|c|c|c|c|c|c|}
\hline & $\begin{array}{l}\text { exposition text } \\
\text { with the genre } \\
\text { approach }\end{array}$ & & & & & & & & & & & & \\
\hline 6. & $\begin{array}{l}\text { Do your skills } \\
\text { in writing } \\
\text { exposition text } \\
\text { after learning } \\
\text { the module } \\
\text { become } \\
\text { improved }\end{array}$ & 4 & 4 & 4 & 5 & & 5 & 4 & 4 & 4 & 4 & $84,44 \%$ & Very good \\
\hline 7. & $\begin{array}{l}\text { Whether the } \\
\text { exposition text } \\
\text { module can } \\
\text { guide you to } \\
\text { independent } \\
\text { learning }\end{array}$ & 4 & 4 & 5 & 5 & & 4 & 5 & 5 & 5 & 5 & $93,33 \%$ & Very good \\
\hline 8. & $\begin{array}{l}\text { What do you } \\
\text { think about the } \\
\text { material } \\
\text { sequence in the } \\
\text { module }\end{array}$ & 5 & 5 & 5 & 4 & & 5 & 4 & 4 & 4 & 4 & $88,88 \%$ & Very good \\
\hline \multicolumn{12}{|c|}{ Average } & $86,66 \%$ & Very good \\
\hline \multicolumn{14}{|c|}{ Quality Integrity (Display) } \\
\hline 1. & $\begin{array}{l}\text { Whether the } \\
\text { illustrations } \\
\text { used in the } \\
\text { module can } \\
\text { add to your } \\
\text { insight }\end{array}$ & 4 & 5 & 3 & & 5 & 4 & 5 & 5 & 4 & 5 & $93,33 \%$ & Very good \\
\hline 2. & $\begin{array}{l}\text { Whether the } \\
\text { decorations } \\
\text { used in the } \\
\text { module can } \\
\text { add to your } \\
\text { attractiveness } \\
\text { in learning } \\
\text { modules }\end{array}$ & 5 & 5 & inta & & 4 & 4 & 4 & 5 & 4 & 5 & $91,11 \%$ & Very good \\
\hline 3. & $\begin{array}{l}\text { Whether the } \\
\text { motivational } \\
\text { words } \\
\text { contained in } \\
\text { the module can } \\
\text { guide you in } \\
\text { learning }\end{array}$ & 4 & 5 & 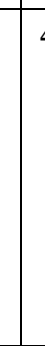 & & 4 & 5 & 5 & 5 & 5 & 5 & $93,33 \%$ & Very good \\
\hline 4. & $\begin{array}{l}\text { What is the } \\
\text { readability of }\end{array}$ & 4 & 5 & 2 & & 5 & 5 & 4 & 4 & 5 & 4 & $88,88 \%$ & Very good \\
\hline
\end{tabular}




\begin{tabular}{|l|l|l|l|l|l|l|l|l|l|l|l|l|}
\hline & $\begin{array}{l}\text { the text } \\
\text { contained in } \\
\text { the module }\end{array}$ & & & & & & & & & & & \\
\hline 5. & $\begin{array}{l}\text { What is the } \\
\text { arrangement or } \\
\text { form of words } \\
\text { I sentences in } \\
\text { the module }\end{array}$ & 5 & 4 & 5 & 5 & 4 & 5 & 4 & 5 & 5 & $93,33 \%$ & Very good \\
Average & & & & & & & & & \\
\hline
\end{tabular}

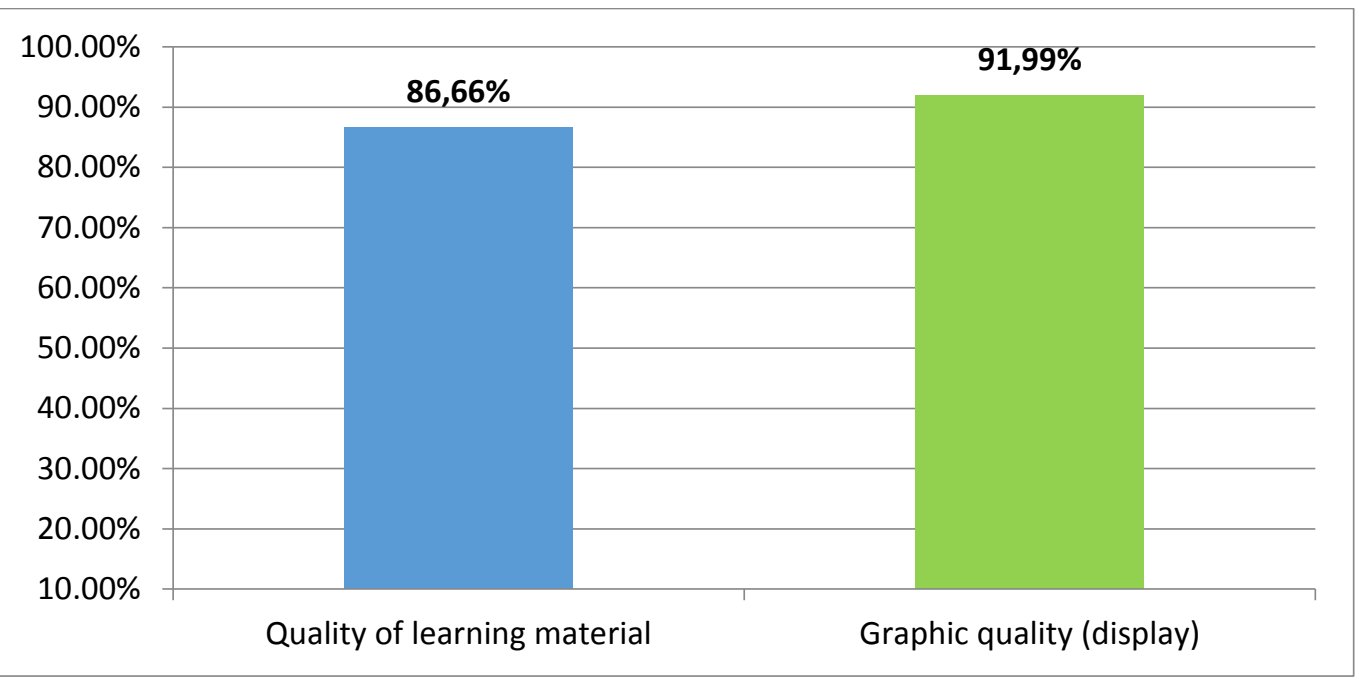

Diagram 3. Percentage of Small Group Trial Results Against Modules for Writing Exposition Texts for Grade X Vocational Students Brigen Katamso

Table 9. Test Results of Limited Groups Against Modules of Writing Exposition Text

\begin{tabular}{|c|c|c|c|c|}
\hline No. & Assessment indicators & Score & Percentage & Category \\
\hline \multicolumn{5}{|c|}{ Quality of Learning Materials } \\
\hline 1. & $\begin{array}{l}\text { Is the learning material of } \\
\text { exposition text writing } \\
\text { easy for you to } \\
\text { understand }\end{array}$ & 132 & $88 \%$ & Very good \\
\hline 2. & $\begin{array}{l}\text { Do you understand the } \\
\text { language used in the } \\
\text { module }\end{array}$ & 140 & $93,33 \%$ & Very good \\
\hline 3. & $\begin{array}{l}\text { Is there a part of learning } \\
\text { material in writing } \\
\text { exposition text that is } \\
\text { difficult for you to } \\
\text { understand }\end{array}$ & 139 & $92,66 \%$ & Very good \\
\hline
\end{tabular}




\begin{tabular}{|c|c|c|c|c|}
\hline 4. & $\begin{array}{l}\text { Can you understand the } \\
\text { usefulness of the genre } \\
\text { approach in writing }\end{array}$ & 137 & $91,33 \%$ & Very good \\
\hline 5. & $\begin{array}{l}\text { Do the steps for writing } \\
\text { exposition text with the } \\
\text { genre approach are easy } \\
\text { for you to do }\end{array}$ & 138 & $92 \%$ & Very good \\
\hline 6. & $\begin{array}{l}\text { Whether your skills in } \\
\text { writing exposition text } \\
\text { after studying the module } \\
\text { has increased }\end{array}$ & 127 & $84,66 \%$ & Very good \\
\hline 7. & $\begin{array}{l}\text { Whether the exposition } \\
\text { text module can lead you } \\
\text { to study independently }\end{array}$ & 133 & $88,66 \%$ & Very good \\
\hline 8. & $\begin{array}{l}\text { What do you think about } \\
\text { the material sequence in } \\
\text { the module }\end{array}$ & 142 & $94,66 \%$ & Very good \\
\hline \multirow{2}{*}{\multicolumn{2}{|c|}{$\begin{array}{l}\text { Average } \\
\text { Quality Integrity (Display) }\end{array}$}} & 136 & $90,66 \%$ & Very good \\
\hline & & & & \\
\hline 1. & $\begin{array}{l}\text { Whether the illustrations } \\
\text { used in the module can } \\
\text { add to your insight }\end{array}$ & 134 & $89,33 \%$ & Very good \\
\hline 2. & $\begin{array}{l}\text { Whether the decorations } \\
\text { used in the module can } \\
\text { add to your attractiveness } \\
\text { in learning modules }\end{array}$ & 141 & $94 \%$ & Very good \\
\hline 3. & $\begin{array}{l}\text { Whether the motivational } \\
\text { words contained in the } \\
\text { module can guide you in } \\
\text { learning }\end{array}$ & 135 & $90 \%$ & Very good \\
\hline 4. & $\begin{array}{l}\text { What is the readability of } \\
\text { the text contained in the } \\
\text { module }\end{array}$ & 134 & $89,33 \%$ & Very good \\
\hline 5. & $\begin{array}{l}\text { What is the arrangement } \\
\text { or form of words / } \\
\text { sentences in the module }\end{array}$ & 138 & $92 \%$ & Very good \\
\hline \multirow{2}{*}{\multicolumn{2}{|c|}{$\begin{array}{l}\text { Average } \\
\text { Total All Average }\end{array}$}} & 136,4 & $90,93 \%$ & Very good \\
\hline & & 136,2 & $90,79 \%$ & Very good \\
\hline
\end{tabular}

The results of obtaining the value of the limited group trial above can be described as follows. Based on the limited group test with the number of respondents as many as 30 students toward the exposition text writing module for students of class X SMK Brigjen Katamso Medan, the average value for the quality of learning material was $90.66 \%$ with a very good category and for graphics quality of $90.93 \%$ with a very good category. The overall total of the group trials was limited to $90.79 \%$ with a very good category. The results of obtaining a percentage of limited group trials can be seen in the diagram below. 


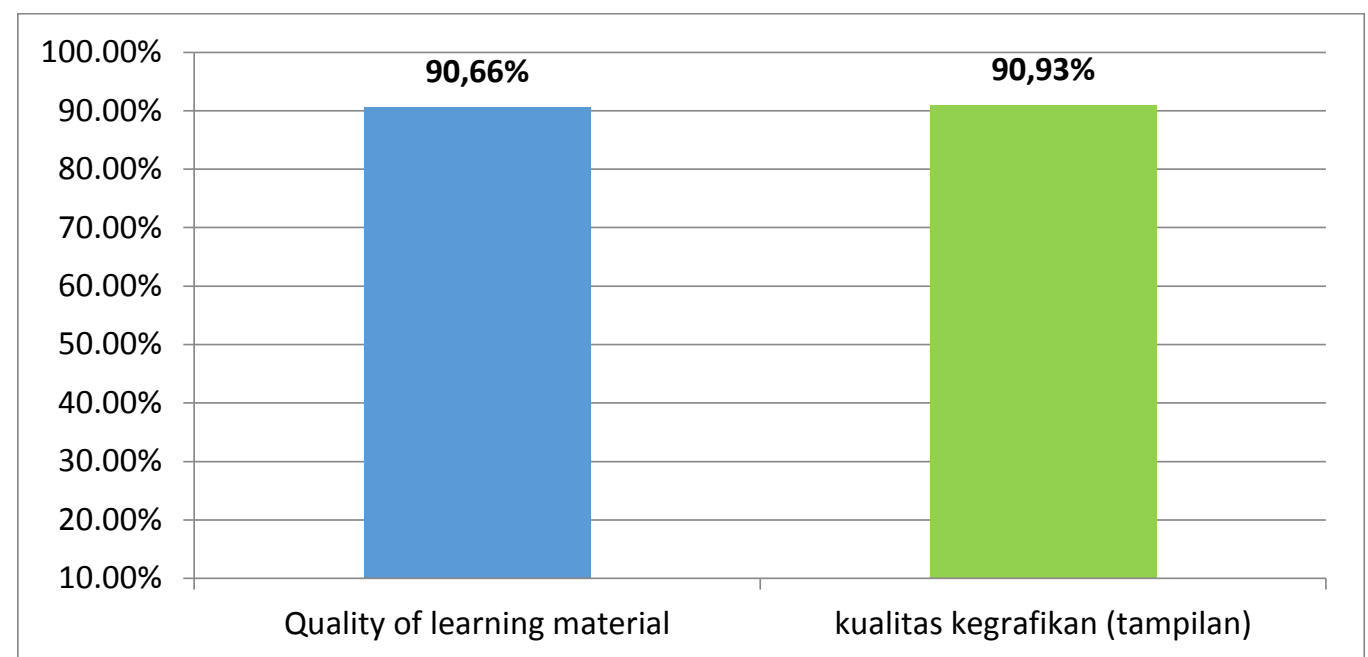

Diagram 4. The Results of Obtaining a Trial Percentage of Limited Groups

Conclusions obtained based on individual trials, small groups and limited groups on the use of exposition text writing modules for students of Grade X vocational high school Brigjen Katamso Medan who have been developed are declared eligible with the overall category of "Very Good". The following are the results of the overall trial module writing exposition text for class X students of Brigadier General Katamso Medan's vocational school.

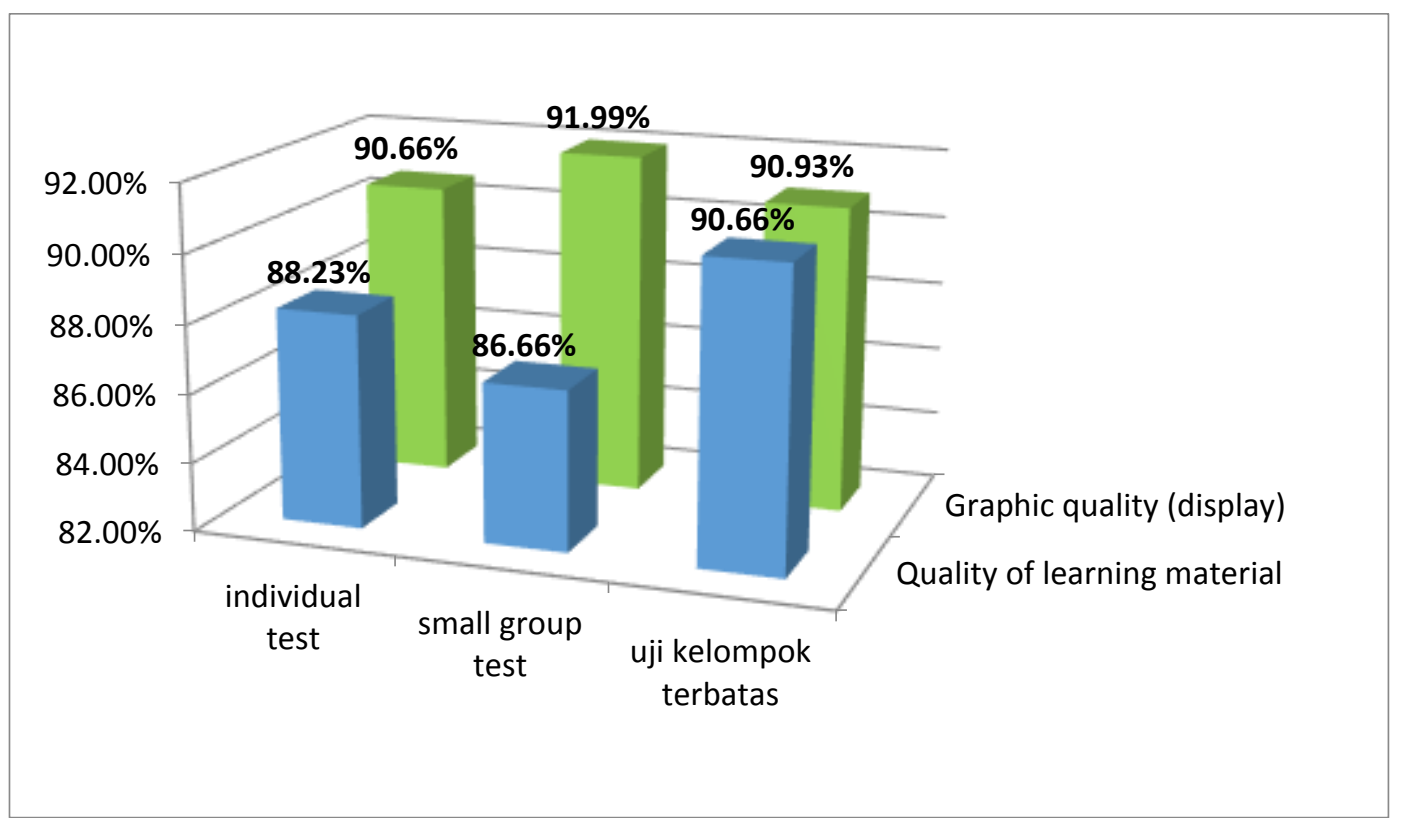

Diagram 5. Comparison of Results of the Results of the Field Trial Percentage

Table 4.10. Obtaining the Pretest and Posttest Results of Writing Exposition Text

\begin{tabular}{|l|l|l|l|}
\hline \multirow{2}{*}{ No. } & \multirow{2}{*}{ Student's Name } & \multicolumn{2}{|l|}{ Score } \\
\cline { 3 - 4 } & & Pretest & Posttest \\
\hline 1. & Ayu Pertiwi & 65 & 78 \\
\hline 2. & Bila S & 70 & 82 \\
\hline
\end{tabular}




\begin{tabular}{|c|c|c|c|}
\hline 3. & Bona Pratama & 68 & 80 \\
\hline 4. & Bunga Citra & 70 & 85 \\
\hline 5. & Caca Bela Tarigan & 75 & 90 \\
\hline 6. & Cicilia Oktaviani & 65 & 80 \\
\hline 7. & Citra Dewi & 68 & 82 \\
\hline 8. & Dedi Hendra P & 70 & 80 \\
\hline 9. & Duma Lasni & 75 & 85 \\
\hline 10. & Donna Indah & 65 & 80 \\
\hline 11. & Ecy Mulastri G & 68 & 85 \\
\hline 12. & Edi Basri M & 70 & 85 \\
\hline 13. & Effendi Syah & 75 & 90 \\
\hline 14. & Hendra & 70 & 85 \\
\hline 15. & Ilham Purnama & 65 & 82 \\
\hline 16. & Jenni Sulastri N & 60 & 80 \\
\hline 17. & Karim Anjas & 68 & 88 \\
\hline 18. & Lelita Simarmata & 75 & 90 \\
\hline 19. & Lili Aisah & 68 & 82 \\
\hline 20. & Parlindungan $\mathrm{N}$ & 60 & 80 \\
\hline 21. & Petrus Purba & 65 & 88 \\
\hline 22. & Rosa Dewi M.P & 65 & 82 \\
\hline 23. & Rusmia Intan & 70 & 85 \\
\hline 24. & Susanti & 70 & 82 \\
\hline 25. & Susilawati Gres & 75 & 90 \\
\hline 26. & Tanti Yanti & 73 & 88 \\
\hline 27. & Vivi Anugrah M & 60 & 80 \\
\hline 28. & Yanti Indah & 70 & 82 \\
\hline 29. & Wahyu & 73 & 80 \\
\hline 30. & Zahra Mentari & 70 & 80 \\
\hline \multicolumn{2}{|c|}{ Average } & 68,70 & 83,55 \\
\hline
\end{tabular}

The results of the pretest and posttest in the table above can be described as follows. The average score of the pretest writing exposition text from 30 students is 68.70. Furthermore, the posttest results obtained an average value of exposition text writing activities of 83.55. Based on the pretest and posttest activities on the application of the exposition text writing module with the genre approach from the average pretest of 68.70 to 83.55 in the posttest level, the average increase was 14.85 .

The gain test is done to see the effectiveness of learning by using the exposition text writing module with the genre approach. This test was conducted in the X-2 class of SMK Brigadier General Katamso Medan with a total of 30 students. The formula used to see the effectiveness of learning is:

$$
\text { Indeks Gain }(g)=\frac{\text { skor posttest }- \text { skor pretest }}{\text { skor masksimal }(100)-\text { skor pretest }}
$$


Table 11. Gain Test (Learning Effectiveness of Writing Exposition Text)

\begin{tabular}{|c|c|c|c|c|c|c|}
\hline No. & Pre-Test & Post-Test & Post-Pre & 100-Pretest & $G$ & Keterangan \\
\hline 1. & 65 & 78 & 13 & 35 & 0,37 & Medium \\
\hline 2. & 70 & 82 & 12 & 30 & 0,40 & Medium \\
\hline 3. & 68 & 80 & 12 & 32 & 0,37 & Medium \\
\hline 4. & 70 & 85 & 15 & 30 & 0,50 & Medium \\
\hline 5. & 75 & 90 & 15 & 25 & 0,60 & Medium \\
\hline 6. & 65 & 80 & 15 & 35 & 0,42 & Medium \\
\hline 7. & 68 & 82 & 14 & 32 & 0,43 & Medium \\
\hline 8. & 70 & 80 & 10 & 30 & 0,33 & Medium \\
\hline 9. & 75 & 85 & 10 & 25 & 0,40 & Medium \\
\hline 10. & 65 & 80 & 15 & 35 & 0,42 & Medium \\
\hline 11. & 68 & 85 & 17 & 32 & 0,53 & Medium \\
\hline 12. & 70 & 85 & 15 & 30 & 0,50 & Medium \\
\hline 13. & 75 & 90 & 15 & 25 & 0,60 & Medium \\
\hline 14. & 70 & 85 & 15 & 30 & 0,50 & Medium \\
\hline 15. & 65 & 82 & 17 & 35 & 0,48 & Medium \\
\hline 16. & 60 & 80 & 20 & 40 & 0,50 & Medium \\
\hline 17. & 68 & 88 & 20 & 32 & 0,62 & Medium \\
\hline 18. & 75 & 90 & 15 & 25 & 0,60 & Medium \\
\hline 19. & 68 & 82 & 14 & 32 & 0,43 & Medium \\
\hline 20. & 60 & 80 & 20 & 40 & 0,50 & Medium \\
\hline 21. & 65 & 88 & 23 & 35 & 0,76 & High \\
\hline 22. & 65 & 82 & 17 & 35 & 0,48 & Medium \\
\hline 23. & 70 & 85 & 15 & 30 & 0,50 & Medium \\
\hline 24. & 70 & 82 & 12 & 30 & 0,40 & Medium \\
\hline 25. & 75 & 90 & 15 & 25 & 0,60 & Medium \\
\hline 26. & 73 & 88 & 15 & 27 & 0,55 & Medium \\
\hline 27. & 60 & 80 & 20 & 40 & 0,50 & Medium \\
\hline 28. & 70 & 82 & 12 & 30 & 0,40 & Medium \\
\hline 29. & 73 & 80 & 7 & 27 & 0,25 & Low \\
\hline 30. & 70 & 80 & 10 & 30 & 0,33 & Medium \\
\hline
\end{tabular}

\section{Conclusion}

The teaching material developed in the exposition text writing material for class $\mathrm{X}$ students is a module designed with a genre approach. The results of the validation carried out by the material expert validator on the development of the exposition text writing module with the genre approach for students of Grade $\mathrm{X}$ vocational high school students obtained an average validation value of $89.11 \%$ with the category "Very Good". The results of the validation carried out by the design expert validator on the exposition text writing module with the genre approach for students in Grade X Vocational High School obtained an overall average value of $90.80 \%$ with the category "Very Good". The teacher's assessment of the exposition text writing module with the genre approach for grade $X$ students obtained an average value of $80.70 \%$ in the "good" category. Obtaining values based on the results of individual field trials obtained an 
average value of $88.23 \%$ with the category "very good", then the small group trials obtained an average value of $89.32 \%$ with the category "very good", and the last the trial of the target group obtained an average value of $90.79 \%$ with the category "very good". The results of students 'exposition text writing ability at the pretest obtained an average value of 68.70 , then at posttest (using the exposition text writing module with genre approach) the average value of students' exposition text writing skills was 83.55.

\section{References}

Aceng, Hasani. 2005. Ikhwal Menulis. Banten: Untirta Press.

Purnomo, et al.2015. Pengembangan buku pengayaan Menulis Teks Eksposisi Bermuatan Nilai-Nilai Sosial untuk Siswa SMP. Jurnal Pendidikan Bahasa dan Sastra Indonesia SELOKA Vol. 4 No. 2, 2015

https://journal.unnes.ac.id/sju/index.php/seloka/article/download/9869/6309 (Accessed February 15, 2018)

Alwasilah, A. Chaedar. 2005. Pokoknya Menulis. Bandung: PT. Kiblat Buku Utama.

Amri, S. And Ahmadi I. K. 2010. Kontruksi Pengembangan Pembelajaran Pengaruhnya Terhadap Mekanisme dan Praktik Kurikulum. Jakarta: Prestasi Pustaka.

Anwar \& Ade Hasnun. 2008. Modul Bahasa Indonesia untuk SMK Kelas XI. Jakarta: Yudistira. Byrne, Donn. 2002. Teaching Writing Skill. England: Longman Group.

Dalman. 2014. Keterampilan Menulis. Jakarta: PT. Raja Grafindo Persada.

Devi, Aulia Vista. 2013. Modul Bahasa Indonesia untuk SMK/MAK Kelas XI. Karanganyar: PT. Pratama Mitra Aksara.

Firdaus, Moch. Malik Al. The Teaching Writing Approaches: Genre: Solution Toward "UN" Reading Test Phenomenon. Jurnal Transformatika Vol. 11 No.1, Maret 2015 http://jurnal.untidar.ac.id/index.php/transformatika/article/view/113/80. (Accsessed on February 20, 2018).

Gie, The Liang. 2002. Terampil Mengarang. Yogyakarta: Andi.

Guido, Ryan Manuel D. 2014. Evaluation of a Modular Teaching Approach in Materials Science and Engineering. American Journal of Educational Research, Vol. 2 No. 11 http://www.researchchgate.net/publication/286166186_evaluation_of_a_Modular_Teac hing_Approach_in_Materials_Science_and_Engineering (Accessed Februari 11, 2018).

Hasanah, et al. 2016. Pengembangan Modul Pembelajaran Menulis Teks Eksposisi dengan Model Problem Based Learning. Jurnal Bahasa dan Sastra Indonesia, Vol. 2 No.5 September 2016; seri G 574-580.

http://ejournal.unp.ac.id/index.php/pbs/article/viewFile/8885/6824 (Accessed on Januari 27, 2018).

Haspari, Intan Permata. 2011. Collaborative Writing: Strategi Meningkatkan Keterampilan Menulis dalam Pembelajaran Genre-Based Writing. Jurnal Lensa Vol.1 No.2 JuliDesember 2011. http://jurnal.unimus.ac.id/index.php/l e n s a / a r t i c l e / d o w n 1 o a d / $183 / 178$ (diakses pada 3 Februari 2018)

Knapp \& M. Knight. 2005. Genre, Text, Grammar: Technology For Teaching And Assessing Writing. New south wales: Kensington.

Lubis, et al. 2015. Pengembangan Modul Pembelajaran Bahasa Indonesia Bermuatan Peta Pikiran Pada Materi Menulis Makalah Siswa Kelas XI SMA/MA. Jurnal Bahasa, Sastra, dan Pembelajaran Vol. 2 No.1 Februari 2015. 
Budapest International Research and Critics in Linguistics and Education (BirLE) Journal

Volume 2, No 3, August 2019, Page: 372-397

e-ISSN: 2655-1470 (Online), p-ISSN: 2655-2647 (Print)

www.bircu-journal.com/index.php/birle emails: birle.journal@gmail.com birle.journal.qa@gmail.com

http://ejournal.unp.ac.id/index.php/bsp/article/d o w n 1 o a d / $5026 / 3978$ (Accessed on February 10, 2018)

Majid, A. 2008. Perencanaan Pembelajaran Mengembangkan Standar Kompetensi Guru. Bandung: PT. Remaja Rodsakarya.

Mufliharsi dan Siti. 2016. Keefektifan Pendekatan Genre-Based Terhadap Pemahaman Teks Bahasa Inggris Peserta Didik Kelas Vii. Jurnal Dieksis Vol.8 No.1, Januari 2016. http://journal.lppmunindra.ac.id/index.php/Dieksis/article/download/664/817 (Accessed on February 20, 2018)

Mulyadi dan Fitria. 2014. Bahasa Indonesia untuk SMA-MA/SMK Kelas X. Bandung: Yrama Widya.

Mulyadi, et all. 2016. Inti Sari Tata Bahasa Indonesia untuk SMP dan SMA. Bandung: Yrama Widya.

Nurgiyantoro, Burhan. 2012. Penilaian Pembelajaran Bahasa Berbasis Kompetensi. Yogyakarta: BPFE-Yogyakarta.

Owon, Robertus Adi Sarjono. 2017. Pengembangan Bahan Ajar Menulis Berbagai Jenis Teks Bertema Kearifan Lokal SIKKA Bagi Siswa SMP. Jurnal JINoP Vol. 3 No. 1, Mei 2017. http://ejournal.umm.ac.id/index.php/jinop/article/download/4318/pdf (Accessed on February 20, 2018)

Pardiyono. 2007. Pasti Bisa! Teaching Genre-Based Writing. Yogyakarta: Andi.

Prastowo, Andi. 2015. Panduan Kreatif Membuat Bahan Ajar Inovatif. Yogyakarta: Diva Press.

Pratama, et al. 2016. Pengembangan Bahan Ajar Menulis Teks Eksposisi Bermuatan Cinta Lingkungan dengan Strategi Pemodelan Untuk Siswa Kelas VII SMP. Jurnal Pendidikan. Vol. 1 No. 3 hal. 448-462.

http://download.portalgaruda.org/article=461307\&val=962\&title=PENGEMBANGAN\%20B AHAN\%20TEKS\%20EKSPOSISI\%BERMUATAN\%20CINTA\%20LINGKUNGAN \%20DENGAN\%20STRATEGI\%20PEMODELAN\%20UNTUK\%20\%20SISWA\%20 KELAS\%20VII\%20SMP.html (Accessed on July 12, 2017).

Pratama. 2015. Pengembangan Multimedia Adobe Flash Player 10 untuk Pembelajaran Keterampilan Menulis Teks Eksposisi Bagi Siswa Kelas VII SMP. UNY: http: // eprints.uny.ac.id/26269/1/.pdf.html (Accessed on July 15, 2017).

Sanjaya, H. Wina. 2013. Kurikulum dan Pembelajaran, Teori dan Praktik Pengembangan Kurikulum Tingkat Satuan Pendidikan (KTSP). Badung: Kencana Prenada Media Group.

Sartini, et al. 2013. Mutiara Gramedia Bahasa Indonesia untuk SMK dan MAK Kelas X. Jakarta: Sinektika.

Sauhenda, et al. 2016. Pengembangan Asesmen Penugasan Menulis Teks Eksposisi dengan Rangsangan Melalui Autentik. Jurnal Pendidikan: Teori, Penelitian, dan Pengembangan Vol. 1 No.3, Maret 2016.

http://journal.um.ac.id/index.php/jptpp/article/download/6153/2597 (Accessed on February 11, 2018).

Sugiyono. 2013. Metode Penelitian Kuantitatif, Kualitatif, dan R\&D. Bandung: Alfabeta.

Sujadi. 2003. Metodologi Penelitian Pendidikan. Jakarta: Rineka Cipta.

Susanto, et al. 2016. Pengembangan Buku Pintar Elektronik Teks Eksposisi Bagi Siswa SMP Kelas VII. Jurnal Pendidikan: Teori, Penelitian, dan Pengembangan Vol. 1 No. 6, Juni 2016. http://journal.um.ac.id/index.php/jptpp/article/download/6356/2711 (Accessed on February 11, 2018) 
Syahputra, Ridwan. 2016. Pengembangan Bahan Ajar Menulis Teks Eksposisi Berbasis Teks Kearifan Lokal di SMA. Tesis. Medan: Unimed https://id.123dok.com/document/6qmd264q-pengembangan-bahan-ajar-menulis-tekseksposisi-b e r b a s i s-t e k s -kearifan-lokal-di-sma.html (Accessed on July 20, 2017). Tarigan, Henry Guntur. 2008. Menulis Sebagai Suatu Keterampilan Berbahasa. Bandung: Angkasa.

Tarigan, Monika Rehmalemna. 2015. Peningkatan Keterampilan Menulis Paragraf Eksposisi Melalui Metode Diskusi dengan Media Koran Siswa Kelas X Sma Negeri 6 Binjai Tahun Pembelajaran 2013/2014. Jurnal Edukasi Kultural Vol.2 No.2 September 2015. http://jurnal.unimed.ac.id/2012/index.php/kultura/article/ (Accessed on Februari 1, 2018).

Widodo, et al. 2008. Panduan Menyusun Bahan Ajar Berbasis Kompetansi. Jakarta: PT. Elex Media Kompetindo.

Widoyoko, S. Eko Putro. 2014. Penilaian Hasil Belajar di Sekolah. Yogyakarta: Pustaka Pelajar. 